\title{
$\begin{array}{ll}\text { Research Square } & \begin{array}{l}\text { Preprints are preliminary reports that have not undergone peer review. } \\ \text { They should not be considered conclusive, used to inform clinical practice, } \\ \text { or referenced by the media as validated information. }\end{array}\end{array}$
}

\section{Feco-prevalence of Helicobacter Pylori Infection and Associated Risk Factors Among Patients Living with HIV/AIDS on ART at Tefera Hailu Memorial General Hospital Sekota, Northeast Ethiopia}

\author{
Mulualem Kiros \\ University of Gondar College of Medicine and Health Sciences \\ Mucheye Gizachew ( $\nabla$ muchegiza@gmail.com ) \\ University of Gondar \\ Teklay Gebrecherkos \\ University of Gondar College of Medicine and Health Sciences
}

\section{Research article}

Keywords: ART, Ethiopia, H. pylori, HIV/AIDS, Prevalence, Risk factors

Posted Date: October 1st, 2020

DOI: https://doi.org/10.21203/rs.3.rs-61684/v1

License: () (i) This work is licensed under a Creative Commons Attribution 4.0 International License. Read Full License 


\section{Abstract}

Background: Globally, two-thirds of humans are infected with Helicobacter pylori (H. pylori), a flagellated Gram negative bacterium, brings peptic ulcer disease and others, mainly, in HIV patients on ART. Its infection among HIV/AIDS patients is not well understood in developing countries, including the study area.

Objective: To assess prevalence of $H$. pylori infection and associated risk factors among HIV/AIDS on ART patients at Tefera Hailu General Memorial hospital Sekota Northeast, Ethiopia.

Methods: An institution based cross sectional study was conducted on HIV/AIDS on ART patients from February to June 2019. A face-to-face interview was administered to assess risk factors for $H$. pylori infection by using semi structured questionnaire. A stool sample was tested for $H$. pylori antigen using the ImmunoCardSTAT HPSA kit as per the manufactures` instruction. Data were entered into excel spreadsheet, cleaned, exported to and analyzed by using the SPSS version 20. Logistic regression model was used to determine the association between explanatory and outcome variables. For all cases, $p$-value $\leq 0.05$ was considered statistically significant.

Results: A total of $88 \mathrm{HIV/AIDS}$ patients on ART were included in this study. Of these, $53.4 \%$ were females, $54.5 \%$ were urban dwellers, $69.3 \%$ were single, $51.1 \%$ had formal education and $58.0 \%$ were non-employed. From these, study participants, a total of 88 stool samples were collected and analyzed, and 57 (64.8\%, 95\% Cl: 54.5-73.9) H. pylori positivity was observed. Among explanatory variables tested, number of family members (AOR: $17.059 ; 95 \% \mathrm{Cl}: 1.751,166.185 ; p$-value $=0.015$ ) and water sources for drinking and cooking (AOR: $0.096 ; 95 \% \mathrm{Cl}: 0.010,0.951 ; p$-value $=0.045)$ were statistically significant with $H$ pylori positivity. Other factors did not show association with $H$. pylori infection ( $p$-value $\geq 0.05$ ).

Conclusion: Prevalence of $H$. pylori among HIV on ART patients was within the ranges of global prevalence (10\%-76\%). Number of family members and water sources for drinking and cooking purpose were found to be factors associated with the $H$. pylori positivity in this study. This finding necessitates the need to design and apply intervention measures that could decrease transmission and thus minimize the clinical consequences of infection.

\section{Background}

Helicobacter pylori (H. pylori) is a bacterium characterized by its gram-negative, spiral-shaped with lophotrichous flagella and urease production causes for peptic ulcer disease (PUD), and gastric carcinoma (1-3). Stomach protects itself from the gastric fluid by mucus that wraps the stomach wall, and the bacterium takes the advantage of this protective mechanism by existing in the thick mucus lining (3). It has various virulence factors such as outer membrane proteins, lipopolysaccharide " 0 " antigen, exotoxins, secretary enzymes and effector cytotoxin besides flagella (4). Its route of transmission appears to be interpersonal and environmental , predominantly through the gastro-oral, faecal-oral and oral-oral from one person's mouth to another $(5,6)$.

Helicobacter pylori infects about half of the world's population and its prevalence varies globally with a greater prevalence reported from the developing countries. Its global estimate was reported at $48.5 \%$ while continental reports were $69.4 \%$ in South America, $37.1 \%$ in North America, 24.4\% in Oceania, 54.6\% in Asia, $47.0 \%$ in Europe and 79.1\% in Africa (7-9). In addition, the overall pooled prevalence of H.pylori infection in a systematic review and meta analysis study was $52.2 \%$, and a sub-group analysis indicated that the highest prevalence was recorded from the Amhara National Regional State (54.6\%) (10).

The trend of H.pylori infection showed a decreasing pattern in the last three decades from 1990 to $2017 ; 64.4 \%$ in the first decade (1990-2000), 62.2\% in the second decade (2001-2011) and 42.9\% in the third decade (2012-2017). This decrement might be related with relative improvements in sanitation, water access, life style and behavioral changes, quality of life and socioeconomic status, and increased awareness on the transmission, diagnosis, eradication therapy, prevention and control of H.pylori infection(10).

The global HIV/AIDS pandemic is still ongoing and about 75 million people have been affected since the beginning of the epidemic, with 37.9 million [32.7-44.0 million] people were living with HIV/AIDS at the end of 2018 (11). Patients with HIV/AIDS experience many form of opportunistic infections including gastrointestinal symptoms The prevalence and role of $\mathrm{H}$. pylori infection among HIV infected patients in gastro duodenal lesions might be different from the general population and it remains blurred whether dyspepsia is adverse effects associated to highly active antiretroviral therapy (HAART) or as a result of $H$. pylori infection (12). The prevalence 
of $\mathrm{H}$. pylori infection in HIV/AIDS patients varies from $10 \%-76 \%$ globally, depending on the time period, geographical location and population (13-17). Various reports revealed that its prevalence in Serbian PLHIV was $34.4 \%$ (18); $22.1 \%$ in China (19); $37.2 \%$ in Brazil (15), $51.5 \%$ in Ghana (20), 22.5\% in Uganda (21) and 73.1\% in Kenya (22).

Another study conducted in the Addis Ababa, Ethiopia demonstrated that of the 106 HIV positive patients, 68 (64.2\%) were positive for anti - H. pylori lgG antibodies (23).

Risk factors associated for acquisition of H. pylori and HIV infections are different: H. pylori is transmitted by gastro - or fecal-oral routes and is associated with low socioeconomic conditions, whereas HIV transmission is through sexual intercourse, infected body fluids, and transplacentally (24).A study carried out in China showed that $H$. pylori infection had no statistically significant association with gender, housing, congested living, educational status, drinking water or toilet facilities (21). Another report from Ghana revealed as lack of tap water and higher was identified as risk factors associated for $H$. pylori infection (20). But, there is a scarcity of data about the prevalence and associated risk factors of $H$. pylori infection in HIV patients in the Ethiopia, particularly, in the study site. Therefore, this study aimed to describe its prevalence in HIV patients and to investigate associated risk factors at the Tefera Hailu General Memorial hospital Sekota Northeast, Ethiopia.

\section{Materials And Methods}

\section{Study Design, Period and Setting}

A cross - sectional study was conducted February to June 2019 at the Tefera Hailu Memorial General Hospital at Sekota, Northeast Ethiopia. The hospital serves for more than half a million people from around and neighboring districts. The hospital is located 720 $\mathrm{Km}$ north from the capital, Addis Ababa and $525 \mathrm{~km}$ from the city of Bahir Dar.

\section{Source population}

All patients who visited at the Tefera Hailu Memorial General Hospital at Sekota, Northeast Ethiopia were the source population.

\section{Study population}

HIV/AIDS patients who had follow up at the ART clinic of the Tefera Hailu Memorial General Hospital within the study period.

\section{Inclusion criteria}

After informed consent, all voluntary ART follow up patients whose HIV positivity was confirmed by both clinically and laboratory examination at Tefera Hailu Memorial General Hospital.

\section{Exclusion criteria}

HIV/AIDS follow up patients who were critically sick, HIV/TB co-infected patients, not voluntary to participate, study participants who received antibiotics for the treatment of $\mathrm{H}$. pylori and/or any other gastro intestinal infection in the previous two weeks,

\section{Study variables}

\section{Dependent variable:}

Prevalence of $H$. pylori infection

\section{Independent variables}


Socio-demographic variables (Gender, Age, Residence, and Marital status), Socio-economical status (educational status, income, family number, type of diet, source of water, and occupation), Socio-cultural practices (Alcohol, smoking, chat chewing and coffee drinking habits), and Clinical factors (HIV/AIDS infections).

\section{Sampling technique}

Eighty eight study participants were included in this study by using a non-probability (convenient) sampling technique from the ART follow up patient's registration list among the 889 HIV/AIDS patients who had ART follow up at Tefera Hailu General Memorial Hospital.

\section{Socio-demographic data collection}

Semi-structured questionnaire (refer additional file) was administered to eligible HIV patients on ART follow up for interview to obtain socio-demographic, socio-economic information and other information on associated risk factors for transmission of $\mathrm{H}$. pylori infection after the consent form obtained. The questionnaire was composed socio-demographic characteristics and it was questionnaire prepared in English version and was translated into Amharic version the patient speaks and then retranslated into English version for analysis, write up and report. Data were collected by trained laboratory personals after they had common understanding of how to collect the data.

\section{Specimen collection and laboratory analysis}

Stool specimen was collected from each study participants by using wide-mouthed clean, dry, and leak proof container. It was then tested for H. pylori antigen with ImmunoCard STAT HpSA kit by following manufacturer's instruction. A 5-6 mm-sized stool sample was added to a vial which contained $1 \mathrm{ml}$ sample diluent and was then emulsified by vortexing for $15 \mathrm{~s}$. The tip of the vial was then snapped off and four drops were added to the sample port of the test cassette. It was then read after 5 min incubation time at ambient temperature. Results were then interpreted as negative when there was a blue line observed in control (C) window only, and as positive when there was an additional pink line in the test $(T)$ window. It was then finally confirmed as positive if the pink line was clearly visible and weakly positive when it was so faint (25).

\section{Quality assurance}

Pre-test was done prior to data collection so as to optimize the experimental set up for $\mathrm{H}$. pylori test. A standardized procedure was strictly followed during stool sample collection, storage and analytical process.

\section{Data analysis}

Data were entered by EPI statistical software and analyzed using SPSS version 20. A result was summarized by frequency, percentages means and $95 \%$ confidence interval to measure the strength of association, bivariate analysis was used to screen those variables which are candidates for multivariate analysis and those variables having $P$ value $\leq 0.2$ were reanalyzed by multivariable analysis to control confounding. The strength of associations with $\mathrm{H}$. pylori infection and independent variables were measured by Adjusted Odds Ratio (AOR) with $95 \%$ confidence interval. Variables with P value $\leq 0.05$ were considered as statistically significant.

\section{Ethical consideration}

The study was conducted after we secured the ethical approval from the School of Biomedical and Laboratory Sciences Ethical Review Committee, University of Gondar. Permission was obtained from Tefera Hailu Memorial General Hospital higher management. Informed consent/assent was obtained from each study participants and /or from their parents/guardians. Study participants were interviewed alone to keep their privacy and data obtained from these patients were coded to keep confidentially. Test results were given to clinicians who are working on ART clinics for appropriate patient management. 


\section{Results}

As it is shown in Table 1, a total of 88 study participants living with HIV on ART follow up were included in this study and majority of them $(64,72.7 \%)$ were in the age range of $>18$ years. Females constituted $47(53.4 \%)$, and single in terms of their marital status accounted $61(69.3 \%)$ of the study participants. Table 2 also described that the majority of the study participants $65(73.9 \%)$ reported that they lived with more than three people in the same house. Sixty four (72.7\%) of the study patients had monthly income of $>1500$ ETB, 76(86.4\%) used water sources for drinking and cooking water from protected-pipe lines, and 72(81.8\%) used toilet for excretion. Regarding the personal habits, $52(59.1 \%)$ drunk alcohol and of which, $3(6.1 \%)$ had alcohol at always time, $65(73.9 \%)$ had coffee and among these, $38(58.5 \%)$ drunk it always. Twenty eight (31.8\%) of the PLWHIV who were included in this study had history of familial infection with H. pylori.

Table 1

Socio-demographic characteristics and $H$. pylori positivity of HIV/AIDS patients who were on ART follow up ( $N=88)$ at Tefera Hailu General Memorial Hospital, Sekota, Northeast

\begin{tabular}{|c|c|c|c|c|c|c|c|c|}
\hline \multicolumn{9}{|c|}{ Ethiopia, 2019} \\
\hline Variables & Categories & $\begin{array}{l}\text { H.pylori } \\
\text { positive,n } \\
(\%)\end{array}$ & $\begin{array}{l}\text { H. pylori } \\
\text { negative, } \\
\mathrm{n}(\%)\end{array}$ & $\begin{array}{l}\text { Total, } \\
\mathrm{n}(\%)\end{array}$ & COR (95\% Cl) & $\begin{array}{l}p- \\
\text { value }\end{array}$ & AOR(95\% Cl) & $\begin{array}{l}p- \\
\text { value }\end{array}$ \\
\hline \multirow[t]{2}{*}{ Sex } & Male & $23(56.1)$ & 18(43.9) & $41(46.6)$ & 1 & & 1 & \\
\hline & Female & $34(72.3)$ & 13(27.7) & $47(53.4)$ & $0.489(0.201,1.188)$ & 0.114 & $0.490(0.196,1.221)$ & 0.126 \\
\hline \multirow[t]{2}{*}{ Age(years) } & $\leq 18$ & 13(54.2) & 11(45.8) & $24(27.3)$ & $0.537(0.205,1.405)$ & 0.205 & $0.649(0.225,1.858)$ & 0.423 \\
\hline & $>18$ & $44(68.8)$ & $20(31.2)$ & $64(72.7)$ & 1 & & 1 & \\
\hline \multirow[t]{2}{*}{ Residence } & Urban & $28(58.3)$ & $20(41.7)$ & $48(54.5)$ & $\begin{array}{l}0.531(0.216 \\
1,307)\end{array}$ & 0.168 & $1.676(0.662,4.243)$ & 0.276 \\
\hline & Rural & $29(72.5)$ & $11(27.5)$ & $40(45.5)$ & 1 & & 1 & \\
\hline \multirow{2}{*}{$\begin{array}{l}\text { Marital } \\
\text { Status }\end{array}$} & Single & $40(66.6)$ & $21(34.4)$ & $61(69.3)$ & 1 & & 1 & \\
\hline & Married & $17(63.0)$ & $10(37.0)$ & $27(30.7)$ & $0.893(0.348,2.291)$ & 0.813 & $1.002(0.361,2.779)$ & 0.998 \\
\hline \multirow{2}{*}{$\begin{array}{l}\text { Education } \\
\text { Level }\end{array}$} & $\begin{array}{l}\text { Non-formal } \\
\text { education }\end{array}$ & $30(69.8)$ & 13(30.2) & $43(48.9)$ & $1.538(0.636,3.719)$ & 0.339 & $1.089(0.404,2.935)$ & 0.866 \\
\hline & $\begin{array}{l}\text { Formal } \\
\text { education }\end{array}$ & $27(60.0)$ & $18(40.0)$ & $45(51.1)$ & 1 & & 1 & \\
\hline \multirow[t]{2}{*}{ Occupation } & Employed & $36(70.6)$ & $15(29.4)$ & $51(58.0)$ & 1 & & & \\
\hline & $\begin{array}{l}\text { Non- } \\
\text { employed }\end{array}$ & $21(56.8)$ & $16(43.2)$ & $37(42.0)$ & $0.547(0.225,1.327$ & 0.182 & $0.512(0.206,1.268)$ & 0.148 \\
\hline
\end{tabular}

The overall prevalence of $H$. pylori infections among the study participants in this study was $57(64.8 \%$; $95 \%$ Cl: $54,5-75.0)$ (Figure 1 ).

Regarding the prevalence of $\mathrm{H}$. pylori in terms of each socio-demographic factors, 34(72.3\%) of the female participants were HpSA positive. Regarding the age, 44(68.8\%) of PLWHIV on ART with $>18$ years old were positive for $H$. pylori, 29(72.5\%) of the rural dwellers, and $30(69.8 \%)$ of patient with non-formal education were found to be infected with H. pylori (table1). About the sociodemographic factors and personal habits, $\mathrm{H}$. pylori positivity was observed among $20(87.0 \%)$ Number of family member's living in the house $\leq 3,16(66.7 \%)$ in patients with $\leq 1500 \mathrm{etb} /$ month income, $11(68.8 \%)$ patients with the habit of open field excretion, $35(67.3 \%)$ in alcohol users, and $19(67.9 \%)$ in those with history of Family infected history with H. pylori (table2). 


\section{Associated risk factors for $H$. pylori infection for HIV/AIDS on ART follow up patients}

As it is detailed in Table 1 above and Table 2 below, the multivariable logistic regression analysis showed that the socio-demographic characteristics of the patients such as sex, age, marital status, residence, occupation, and educational level and many socioeconomic status and personal habits like Monthly income, Do you wash your hand after toilet?, use of alcohol and coffee, chewing chat and family infected history with $H$. pylori did not show statistical association with $H$. pylori infection. Number of family member's living in the house with $\leq 3$ had 17 (AOR=17.059; 95\%Cl: $1.751,166.185)$ times more risk $(p=0.015)$ for $H$. pylori infections than their counterparts. In addition, patients who had rivers and bore-holes originated source of drinking and cooking water had the odds of $0.096(\mathrm{AOR}=0.096 ; 95 \% \mathrm{Cl}$ : $0.010,0.951) p=0.045$ times more protected from $\mathrm{H}$. pyloi infections than those who used protected pipe line water sources. Those study participants who had usual alcohol use, smoking cigarette and chat chewing habits and those who did not have hand wash practice after toilet were all infected with $\mathrm{H}$. pylori though it was not possible to assess for the possible association of these risk factors to $H$. pylori infections by calculating the odds owing to small numbers of cells in a 2 by 2 table (Table 2). 
Table 2

Socio- economic factors and personal habits with H. pylori positivity in HIV/AIDS patients who were on ART follow up $(\mathrm{N}=88)$ at Tefera Hailu General Memorial Hospital, Sekota, Northeast Ethiopia, 2019

\begin{tabular}{|c|c|c|c|c|c|c|c|c|}
\hline Variables & Categories & $\begin{array}{l}\text { H. pylori } \\
\text { positive, } \\
\mathrm{n}(\%)\end{array}$ & $\begin{array}{l}\text { H. pylori } \\
\text { Negative, } \\
\mathrm{n}(\%)\end{array}$ & Total & $\operatorname{COR}(95 \% \mathrm{Cl})$ & $\begin{array}{l}p- \\
\text { value }\end{array}$ & AOR $(95 \% \mathrm{Cl})$ & $\begin{array}{l}p \text { - } \\
\text { value }\end{array}$ \\
\hline \multirow{3}{*}{$\begin{array}{l}\text { Number } \\
\text { of family } \\
\text { member's } \\
\text { living in } \\
\text { the } \\
\text { house }\end{array}$} & $\leq 3$ & $20(87.0)$ & $3(13.0)$ & $23(26.1)$ & $5.045(1.363,18.680)$ & 0.015 & $17.059(1.751,166.185)$ & 0.015 \\
\hline & & & & & & & & \\
\hline & $>3$ & $37(57.0)$ & $28(43.0)$ & 65(73.9) & 1 & & 1 & \\
\hline \multirow[t]{2}{*}{$\begin{array}{l}\text { Monthly } \\
\text { income? }\end{array}$} & $\begin{array}{l}\leq 1500 \\
\text { ETB }^{\star}\end{array}$ & $16(66.7)$ & 8(33.3) & $24(27.3)$ & $1.122(0.417,3.021$ & 0.820 & $2.581(0.739,9.014)$ & 0.137 \\
\hline & $>1500$ ETB & $41(64.0)$ & $23(36.0)$ & $64(72.7)$ & 1 & & & \\
\hline \multirow{2}{*}{$\begin{array}{l}\text { Source of } \\
\text { drinking } \\
\text { and } \\
\text { cooking } \\
\text { water? }\end{array}$} & $\begin{array}{l}\text { rivers and } \\
\text { bore-holes }\end{array}$ & $6(50.0)$ & $6(50.0)$ & 12(13.6) & $0.490(0.143,1.675)$ & 0.255 & $0.096(0.010,0.951)$ & 0.045 \\
\hline & $\begin{array}{l}\text { protected- } \\
\text { pipe lines }\end{array}$ & $51(67.1)$ & 25(32.9) & 76(86.4) & 1 & & 1 & \\
\hline \multirow{2}{*}{$\begin{array}{l}\text { Where do } \\
\text { you } \\
\text { excrete? }\end{array}$} & open field & $11(68.8)$ & $5(31.3)$ & 16(18.2) & $1.243(0.389,3.972)$ & 0.713 & $2.121(0.390,11.541)$ & 0.384 \\
\hline & toilet & $46(63.9)$ & $26(36.1)$ & $72(81.8)$ & 1 & & 1 & \\
\hline \multirow{2}{*}{$\begin{array}{l}\text { Do you } \\
\text { wash } \\
\text { your } \\
\text { hand } \\
\text { after } \\
\text { toilet? }\end{array}$} & No & $2(100.0)$ & $0(0.0)$ & $2(2.3)$ & - & - & - & - \\
\hline & Yes & $55(64.0)$ & $31(36.0)$ & $86(97.3)$ & - & - & - & - \\
\hline \multirow{2}{*}{$\begin{array}{l}\text { Hand } \\
\text { wash } \\
\text { material }\end{array}$} & $\begin{array}{l}\text { without } \\
\text { soap }\end{array}$ & $39(65.0)$ & $21(35.0)$ & $60(68.2)$ & $1.032(0.404,2.635)$ & 0.948 & $2.318(0.657,8.181)$ & 0.191 \\
\hline & with soap & 18(64.3) & $10(35.7)$ & $28(48.3)$ & 1 & & 1 & \\
\hline \multirow{2}{*}{$\begin{array}{l}\text { Do you } \\
\text { drink } \\
\text { alcohol? }\end{array}$} & No & $22(61.1)$ & 14(38.9) & $36(40.1)$ & 1 & & 1 & \\
\hline & Yes & $35(67.3)$ & $17(32.7)$ & $52(59.1)$ & $1.310(0.540,3.177)$ & 0.550 & $1.890(0.524 .6 .814)$ & 0.331 \\
\hline \multirow{2}{*}{$\begin{array}{l}\text { How } \\
\text { often you } \\
\text { drink } \\
\text { alcohol? }\end{array}$} & Sometimes & $30(65.2)$ & $16(34.8)$ & $46(93.9)$ & - & - & - & - \\
\hline & Always & $3(100.0)$ & $0(0.0)$ & $3(6.1)$ & - & - & - & - \\
\hline \multirow{2}{*}{$\begin{array}{l}\text { Do you } \\
\text { drink } \\
\text { coffee? }\end{array}$} & No & 16(70.0) & $7(30.4)$ & $23(26.1)$ & 1 & & 1 & \\
\hline & Yes & $41(63.0)$ & $24(37.0)$ & 65(73.9) & $0.747(0.269,2.075)$ & 0.576 & - & - \\
\hline How & Sometimes & 14(51.9) & $13(48.1)$ & $27(41.5)$ & 1 & & 1 & \\
\hline
\end{tabular}




\begin{tabular}{|c|c|c|c|c|c|c|c|c|}
\hline & Always & $26(68.4)$ & 12(31.6) & $38(58.5)$ & $2.012(0.726,5.572)$ & 0.179 & $1.799(0.541,5.981)$ & 0.338 \\
\hline \multirow{2}{*}{$\begin{array}{l}\text { Smoke } \\
\text { cigarette }\end{array}$} & No & $55(64.0)$ & $31(36.0)$ & $86(97.7)$ & - & - & - & - \\
\hline & Yes & $2(100.0)$ & $0(0.0)$ & $2(2.3)$ & - & - & - & - \\
\hline \multirow{2}{*}{$\begin{array}{l}\text { Chew } \\
\text { kchat? }\end{array}$} & No & $54(63.5)$ & $31(36.5)$ & $85(96.6)$ & - & - & - & - \\
\hline & Yes & $3(100.0)$ & $0(0.0)$ & $3(3.4)$ & - & - & - & - \\
\hline \multirow{2}{*}{$\begin{array}{l}\text { Is your } \\
\text { diet? }\end{array}$} & Non-Salty & $25(62.5)$ & 15(37.5) & $40(45.5)$ & 1 & & 1 & \\
\hline & Salty & $32(66.7)$ & 16(33.3) & $48(54.5)$ & $1.200(0.499,2.886)$ & 0.684 & $0.861(0.250,2.963)$ & 0.813 \\
\hline \multirow{2}{*}{$\begin{array}{l}\text { Family } \\
\text { infected } \\
\text { history } \\
\text { with } \mathrm{H} \text {. } \\
\text { pylori }\end{array}$} & No & $38(63.3)$ & $22(36.7)$ & $60(68.2)$ & 1 & & 1 & \\
\hline & Yes & 19(67.9) & $9(32.1)$ & 28(31.8) & $1.222(0.472,3.164)$ & 0.679 & $2.137(0.492,9.276)$ & 0.311 \\
\hline
\end{tabular}

\section{Discussion}

H. pylori infection is known as a public health problem across the globe. Its prevalence vary geographically; a study showed that the developing countries have much higher infection rates (90.0\%) than the developed countries (1.2-12.0\%) (26).. Prevalence of $H$. pylori infections in HIV patients on ART and associated risk factors has not been well documented in different corners of the subSaharan Africa, where more than $66.7 \%$ of HIV-infected individuals exist, and where, at the same time, the vast majority of the population gets infected with $H$. pylori during childhood $(1,27)$.

In the present study, it was found that the prevalence of $H$. pylori infection in people living with HIV/AIDS on ART was $64.8 \%$. It is similar with a result reported from Ethiopia 64.2\% (23); however, various studies in Ethiopia and other countries showed that the overall prevalence of $\mathrm{H}$. pylori infection in adult dyspeptic patients, as found by the different diagnostic methods, varied between $69.0 \%$ and $91.0 \%(28), 57.9 \%-69.7 \%$ in Iran (29), and $73.1 \%$ in Kenya (30).

The prevalence of this study is higher than reports from different parts of the world such as studies conducted in Brazil where $H$. pylori infection among HIV positive patients ranges from $32.38 \%(12)$ to $37,2 \%$, but lower among HIV negative study participants (75.2\%)(15); $51.0 \%$ in Romania (30), 8/45(17.7\%) by serology and 9/45(20.0\%) by ${ }^{13} \mathrm{C}$-urea breath test in Italy (31); $17.3 \%$ in Taiwan (16) and $22.1 \%$, China(32) in HIV-infected than in non- infected (63.5\% and $44.8 \%$, respectively) patients; $18.2-34.4 \%$, in Serbia depending on the study period, namely the type of applied ART (18);; $51.5 \%$ in HIV patients in Ghana, but lower than HIV negative study groups (88.0\%) (20); 46.8\% in Nigeria (4); 28/56(50.0\%) in HIV positive patients and 31/56 (55.0\%) in HIV negative controls in Cameron (33); $22.5 \%$ in Uganda (21). A study conducted in Addis Ababa, Ethiopia among dyspeptic and non-dyspeptic HIV patients showed $31.6 \%$ H. pylori (34) which is lower than the finding observed in our study.

The H. pylori prevalence observed in the current study in PLWHIV is lower than studies conducted in various areas of the world such as $75.0 \%$ among PLWHIV, and $87.0 \%$ in HIV negative study participants in Italy (35); 81.0\% in Zambia (36); 68 (75.6\%) in Nigeria (37); 36/44 (81.8\%) among HIV positives and 148/171 (86.5\%) in HIV negative dyspeptic patients in Northwest Ethiopia (38). The sex specific prevalence of $\mathrm{H}$. pylori in our study was shown that female study participants accounted $72.3 \%$ which is higher than that of male participants. Similarly, a study conducted in Nigeria showed that $47(33.8 \%)$ were women and 18 (13\%) were men (4); 372 (75.9\%) females in Ghana (20); 41/61 (67.2\%) females in Nigeria (37). 
This overall disagreement of $H$. pylori prevalence in different studies might be due to the use of different methods for the diagnosis of $H$. pylori between the present study and the previous studies where we used the faecal antigen (ImmunoCardSTAT HpSA kit) test method where as many other studies used culture, ImmunoCardSTAT HpSA rapid test kit and /or SD Bioline H. pylori Ag rapid test kit, serological assay for IgG / IgA antibodies, H. pylori ELISA kit, ${ }^{13} \mathrm{C}$-urea breath test, histology in either in single or in combination. In addition, this variation might be gone with the type of specimens collected and processed where we collected and analyzed stool specimen, but other studies used different specimens such as stool, blood, and biopsies specimens in combination or single type. The sample size included in the study might also have a contribution for such a variation of $H$. pylori prevalence in PLWHIV in different studies conducted all over the globe. .

Regarding to the factors associated to $H$ pylori infection among HIV positive patients, we did not find statistically significant differences regarding the socio-demographic factors such as sex $(p=0.126)$, age $(p=0.423)$, residence $(p=0.276)$, marital status $(p$ $=0.998)$, educational level $(p=0.866)$, and occupation $(p=0.148)$ with that of $H$. pylori infections among the PLWHIV. In addition, $H$. pylori infection was not found to be statistically significantly associated risk factors to personal habits of our study participants such as alcohol $(p=0.331)$ and coffee $(p=0.338)$ use, chat chewing, smoking cigarette, use of salty diet and lack of hand washing practice after toilet $(p=0.190)$. In agreement with this, level of education $(p=0.416)$, lack of employment $(p=0.673)$, personal factors like alcohol consumption $(p=0.618)$ and cigarette smoking were not associated with $H$. pylori positivity in a study conducted in Addis Ababa, Ethiopia (34). In contrary to this, drinking coffee $(p=0.025)$ and chat chewing $(p=0.008)$ were found to be the risk factors associated with $\mathrm{H}$. pylori infections of the patients in a study conducted in Northwest part of Ethiopia (39). Another study done in Northwest Ethiopia before a decade demonstrated that $H$ pylori infection is very high and associated with history of alcohol intake $(p<0.01)$ and older age $(p<0.01)(38)$.

It was found that the study participants with $\leq 3$ number of family members living in the same house had about $6.0 \%$ more vulnerable for $H$. pylori infection as compared with those who had $>3$ family members $(p=0.015)$, and those who used rivers and bore-holes as their source of drinking and cooking water were about $9.6 \%$ protective of $H$. pylori infections compared to those who used their water sources from protected-pipe lines $(p=0.045)$. Unlike to this, a study conducted in Northwest Ethiopia showed that the use of unhygienic water supply from rivers and well are contributing risk factors for infections of with $\mathrm{H}$. pylori $(p=0.017)$ as compared to those who had water from protected pipeline sources (39). Another study conducted in the Uganda revealed that the number of family members living in same house did not show a statistically significant association to the $H$. pylori infections of the patients $(p=0.93)$, but lower age was fond to be a contributing factors for $H$. pylori positivity (21).

The variations observed about risk factors associated with H. pylori infections in different studies are possibly owing to the size of the study participants included, the differences in socio-economic levels, personal habits and variations in individual practices and geographical locations. Moreover, as shown in most epidemiological data, the living standards associated with improved hygiene (toilets, running water, safe drinking water, and hand washing practice within families) are associated with reduction in the infection prevalence. In most of the high standard of living countries, the prevalence is nowadays low and a decreasing trend has been noted $(40,41)$. It is the reason why the infection rate is especially higher in developing countries, where contaminated water, combined with social hardships and poor sanitary conditions, plays a key role.

\section{Limitation}

The limitation of this study was that the numbers of the study participants (HIV patients) were small

\section{Conclusion}

H. pylori is a common bacterium, and about $50.0 \%$ of the world's population has been estimated to be infected. Our data showed that the prevalence of its infection was within the ranges reported by various studies from different parts of the globe. Use of river water source and family members $\leq 3$ in a house were statistically significant associated risk factors to $H$ pylori infections of the PLWHIV. Improving the water supply and sanitary conditions to decrease the prevalence of $\mathrm{H}$. pylori in Ethiopia, mainly in the study area is mandatory.

\section{Declarations}




\section{Ethics approval and consent to participate}

It is done after we secured ethical approval from the School of Biomedical and Laboratory Sciences, College of Medicine and Health Sciences, University of Gondar. Permission was obtained from the Tefera Hailu Memorial General Hospital, Sekota administrative bodies. After giving a brief description about the purpose of the study, eligible HIV patients gave informed written consent for their participation in the questionnaire of this study. Confidentiality was ensured using code numbers than names and keeping the data locked.

\section{Consent for publication}

Not applicable

\section{Availability of data and materials}

All data generated or analyzed during this study are included in this published article.

\section{Competing interests}

The authors declare that they have no competing interests

\section{Funding}

Financial and material supports were from the University of Gondar and the Tefera Hailu Memorial General Hospital, Ethiopia. The funders had no role in study design, data collection and analysis, decision to publish, or preparation of the manuscript.

\section{Authors' contributions}

MK is the principal investigator of the study and he performed the design of the study, data management, study supervision, analysis, interpretation of data and manuscript preparation. MG and TG: involved in the designing, supervision, acquisition of data and critical review of the manuscript. Finally, both authors read and approved the final manuscript for publication

\section{Acknowledgments}

The authors would like to express their gratitude to the University of Gondar for the financial support provided in the study. Likewise, we would like to acknowledge all the study participants who volunteered to give samples and respond to the questionnaire. Our special thanks goes to the Tefera Hailu Memorial General Hospital administration for their unreserved support during the data collection.

\section{Authors` detail or affiliation}

${ }^{1}$ Department of Medical Microbiology, School of Biomedical and Laboratory Sciences, College of Medicine and Health Sciences, University of Gondar, P. O. Box 196, Gondar, Ethiopia

\section{References}

1. Versalovic J. Helicobacter pylori. Pathology and diagnostic strategies. Am J Clin Pathol. 2003;119(3):403-12.

2. Kusters JG, van Vliet AH, Kuipers EJ. Pathogenesis of Helicobacter pylori infection. Clin Microbiol Rev. 2006;19(3):449-90.

3. Lee A. The microbiology and epidemiology of Helicobacter pylori infection. Scand J Gastroenterol Suppl. 1994;201:2-6. 
4. Joseph AA, Onyemocho A, Rosemary AA, OchemeJulius O, Murna A, Amali A, et al. Prevalence of helicobacter pylori infection among HIV-1 infected patients using stool antigen tests in jos, north-central, Nigeria. Govaresh. 2016;21(1):57-65.

5. Eusebi LH, Zagari RM, Bazzoli F. Epidemiology of Helicobacter pylori Infection. Helicobacter. 2014;19(Suppl. 1):1-5.

6. Goh KL, Chan WK, Shiota S, Yamaoka Y. Epidemiology of Helicobacter pylori infection and public health implications. Helicobacter. 2011;16(Suppl 1)::1-9.

7. Hunt RH, Xiao SD, Megraud F, Leon-Barua R, Bazzoli F, van der Merwe S, et al. Helicobacter pylori in developing countries. World Gastroenterology Organisation Global Guideline. J Gastrointestin Liver Dis. 2011;20(3):299-304.

8. Torrres BZ, Lucero Y, Lagomarcino AJ, A OM, George S, JP T, et al. Review: Prevalence and dynamics of Helicobacter pylori infection during childhood. Helicobacter. 2017;22(5):e12399.

9. Hooi JKY, Lai WY, Ng WK, Suen MMY, Underwood FE, Tanyingoh D, et al. Global Prevalence of Helicobacter pylori Infection: Systematic Review and Meta-Analysis. Gastroenterology. 2017;153(2):420-9.

10. Melese A , Genet C, Zeleke B, Andualem T. Helicobacter pylori infections in Ethiopia; prevalence and associated factors: a systematic review and meta-analysis. Gastroenterology 2019;19(8):1-15.

11. UNAIDS. Global HIV \& AIDS statistics - 2019 fact sheet: Summary of the global HIV epidemic data. Avaliable at https://wwwunaidsorg/en/resources/fact-sheet. 2019.

12. Werneck-Silva AL, Prado IB. Dyspepsia in HIVinfected patients' under highly active antiretroviral therapy. J Gastroenterol Hepatol. 2007;22(17):12-6.

13. Nkuize M, De Wit S, Muls V, Arvanitakis M, Buset M. Upper gastrointestinal endoscopic findings in the era of highly active antiretroviral therapy. HIV Medicine. 2010;11(6):412-7.

14. Marano BJ, Smith F, Bonanno CA. Helicobacter pylori prevalence in acquired immunodeficiency syndrome. American Journal of Gastroenterology. 1993;88(5):687- 90.

15. Fialho AB, Braga-Neto MB, Guerra EJ, Fialho AM, Fernandes $K C$, Sun JL, et al. Low prevalence of H. pylori infection in HIVpositive patients in the northeast of Brazil. BMC Gastroenterology. 2011;11(1)::13.

16. Chiu HM, Wu MS, Hung CC, Shun CT, Lin JT. Low prevalence of Helicobacter pylori but high prevalence of cytomegalovirusasociated peptic ulcer disease in AIDS patients: comparative study of symptomatic subjects evaluated by endoscopy and CD4 counts. Journal of Gastroenterology and Hepatology 2004;19(4):423 - 8.

17. Mohamed FA, Lule GN, Nyong'o A, Bwayo J, Rana FS. Prevalence of Helicobacter pylori and endoscopic findings in HIV seropositive patients with upper gastrointestinal tract symptoms at Kenyatta National Hospital, Nairobi. East African Medical Journal 2002;79(5):226 - 31.

18. Spurnic AR, Brmbolic B, Stoj2ic Z, Pekmezovic T, Bukumiric Z, Korac M, et al. The increasing prevalence of HIV/Helicobacter pylori co-infection over time, along with the evolution of antiretroviral therapy (ART). PeerJ 5:e3392; DOI 107717/peerj3392. 2017:1-14.

19. Lv F-J, Luo X-L, Meng X, Jin R, Ding H-G Z, hang S-T. A low prevalence of H pylori and endoscopic findings in HIV-positive Chinese patients with gastrointestinal symptoms. World Journal of Gastroenterology. 2007;13(41):5492.

20. Sarfo FS, Eberhardt KA, Dompreh A, Kuffour EO, Soltau M, Schachscheider M, et al. Helicobacter pylori infection is associated with higher CD4 T cell counts and lower HIV-1 viral loads in ART-naïve HIV-positive patients in Ghana. PloS One.

2015;10(11):e0143388.

21. Hestvik E, Tylleskar T, Ndeezi G, Grahnquist L, Olafsdottir E, Tumwine JK, et al. Prevalence of Helicobacter pylori in HIV-infected, HAART-naïve Ugandan children: a hospitalbased survey. Journal of the International AIDS Society. 2011;14(1):34.

22. Mohamed FA, Lule G, Nyong'o A, Bwayo J, Rana F. Prevalence of Helicobacter pylori and endoscopic findings in HIV seropositive patients with upper gastrointestinal tract symptoms at Kenyatta National Hospital, Nairob. East African medical journal. 2002;79(5):226-31.

23. Teka B, Gebre - Selassie S, Abebe T. Sero - Prevalence of Helicobacter Pylori in HIV Positive Patients and HIV Negative Controls in St. Paul's General Specialized Hospital, Addis Ababa, Ethiopia. Science Journal of Public Health. 2016; 4(5):387-93.

24. Nevin DT, Morgan CJ, Graham SY, Genta RM. Helicobacter pylori Gastritis in HIV-Infected Patients: A Review. Helicobacter 2014;19:323-9. 
25. Chisholm SA, Watson CL, Teare EL, Saverymuttu S, Owen RJ. Non-invasive diagnosis of Helicobacter pylori infection in adult dyspeptic patients by stool antigen detection: does the rapid immunochromatography test provide a reliable alternative to conventional ELISA kits? Journal of medical microbiology. 2004;63(7):623-7.

26. Frenck WR, Clemens J. Helicobacter in the developing world. Microbes Infect 2003;5:705-13.

27. Vandenplas Y. Helicobacter pylori infection. World J Gastroenterol. 2000;6(1):20-31.

28. Tadege T, Mengistu Y., Desta K., Asrat D. Seroprevalence of Helicobacter pylori Infection in and its Relationship with ABO Blood Groups EthiopJ Health Dev. 2005;19(1):55-9.

29. Kafil HS, Jahromi FF, Hajikhani B, Pirayeh SN, Aghazadeh M. Screening for the presence of Helicobacter pylori in stool of HIVpositive patients. Journal of AIDS and HIV Research. 2011;3(4):85-7.

30. Nina-loana Ş, Simona B, Carmen C, Brîndușa T, Iringó Z-K, Andrea I, et al. Helicobacter pylori infection in HIV-positive versus HIVnegative patients. Acta Medica Marisiensis. 2012;58(6):454-7.

31. Lionetti P, Amarri S, Silenzi F, Galli L, Cellini M, de Martino M, et al. Prevalence of Helicobacter pylori Infection Detected by Serology and 13C-Urea Breath Test in HIV-1 Perinatally Infected Children. J Pediatr Gastroenterol Nutr. 1999;28(3):301-6.

32. Fu-Jing LV, Luo X, Xin M, Jin R, Hui-Guo D, S: Z. A low prevalence of H pylori and endoscopic findings in HIVpositive Chinese patients with gastrointestinal symptomS. World J Gastroenterol. 2007;13(41):5492-6.

33. Andoulo FA, Kowo M, Ngatcha G, Ndam AN, Awouoyiegnigni B, Sida MB, et al. Prevalence of Helicobacter pylori prevalence and upper gastrointestinal endoscopy in HIV/AIDS patients with gastrointestinal symptoms in the University Teaching Hospitals in Cameroon. Me'decine et Sante' Tropicales. 2016;26(3): 278-82.

34. Seid G, Desta K, Tsegaye A. Helicobacter pylori Infection among Dyspeptic and Non-Dyspeptic HIV Patients at Yeka Health Center Addis Ababa, Ethiopia; Case Control Study. J Clin Chem Lab Med. 2018;1(2):114.

35. Fernando N, Holton J, Zulu I, Vaira D, Mwaba P, Kelly P. Helicobacter pylori infection in an urban African population. J clin microbiol. 2001;39(4):1323-7.

36. Kayamba V, Asombang AW, Mudenda V, Lisulo MM, Sinkala E, Mwanamakondo S, et al. Gastric adenocarcinoma in Zambia: a case-control study of HIV, lifestyle risk factors, and biomarkers of pathogenesis. South African Medical Journal. 2013;103(4):255-9.

37. Eze EU, Ugiagbe RA. Seroprevalance of Helicobacter pylori amongst anti retroviral naive HIV infected persons in Benin City, Nigeria. Nigerian Journal of Gastroenterology and Hepatology. 2010;2(1).

38. Moges F, Kassu A, Mengistu G, Adugna S, Andualem B, Nishikawa T, et al. Seroprevalence of Helicobacter pylori in dyspeptic patients and its relationship with HIV infection, ABO blood groups and life style in a university hospital, Northwest Ethiopia. World J Gastroenterol. 2006;12(12):1957-61.

39. Negash M, Baynes HW, Geremew D. Helicobacter pylori Infection and Its Risk Factors: A Prospective Cross-Sectional Study in Resource-Limited Settings of Northwest Ethiopia. Can J Infect Dis Med Microbiol. 2018;9463710:7 pages.

40. Graham DY. History of Helicobacter pylori, duodenal ulcer, gastric ulcer and gastric cancer. World J Gastroenterol. 2014;20(18):5191-204.

41. Mentis A, Lehours P, Mégraud F. Epidemiology and Diagnosis of Helicobacter pylori infection. Helicobacter. 2015;20(Suppl 1):1-7.

\section{Figures}




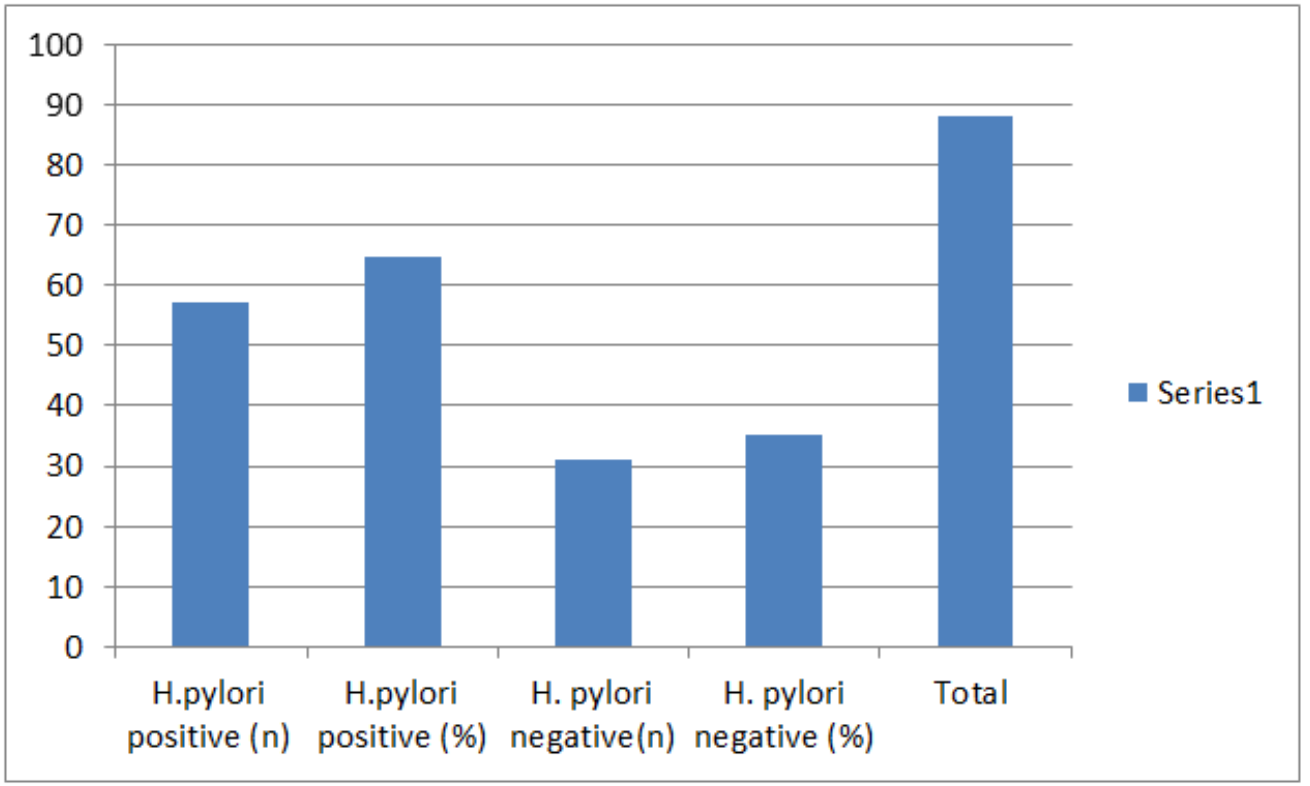

\section{Figure 1}

Prevalence of $\mathrm{H}$. pylori infection among HIV patients on ART attending at the Tefera Hailu Memorial General Hospital Sekota, Northeast Ethiopia

\section{Supplementary Files}

This is a list of supplementary files associated with this preprint. Click to download.

- Additionalfile.docx 